INSIGHTS INTO REGIONAL DEVELOPMENT

ISSN 2669-0195 (online) http://jssidoi.org/IRD/

2021 Volume 3 Number 1 (March)

http://doi.org/10.9770/IRD.2021.3.1(6)

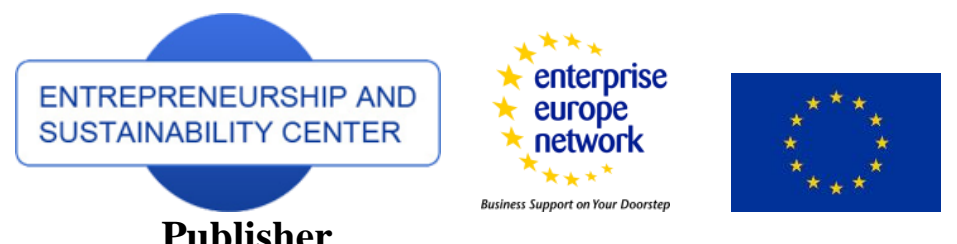

http://jssidoi.org/esc/home

\title{
COMPARATIVE ANALYSIS OF THE VIEWS AND ATTITUDES OF ELEMENTARY AND SECONDARY SCHOOL PUPILS FROM THE CZECH REPUBLIC AND SLOVAK REPUBLIC ON THE DIVISION OF THE CZECH AND SLOVAK FEDERATIVE REPUBLIC (ČSFR)*
}

\author{
Marcel Lincényi ${ }^{1}$, Matej Mindár ${ }^{2}$ \\ 1,2 Alexander Dubček University of Trenčin, Študentská 1639/2, 91101 Trenčín, Slovakia \\ E-mails: ${ }^{1}$ marcel.lincenyi@tnuni.sk $;{ }^{2}$ matej.mindar@tnuni.sk
}

Received 15 July 2020; accepted 20 December 2020; published 30 March 2021

\begin{abstract}
This paper addresses current views and attitudes of pupils on the division of the Czech and Slovak Federative Republic (CSFR). The current young generation has not experienced the division of the former common state of Czechs and Slovaks. They thus gain their opinions and knowledge on this issue not only from the school environment, but also from their parents or grandparents. The main research objective was a comparative analysis of the current views and knowledge of selected elementary and secondary school pupils in the Czech Republic and the Slovak Republic on the division of CSFR into two separate States. Through their research method, the authors identified how selected respondents perceived post-November political processes leading to the constitutional and peaceful division of the Czech and Slovak Federative Republic. One of the positive benefits of their study was the fact that most Slovak and Czech respondents perceived positively the emergence of the independant Slovak and Czech Republics as of 1 January 1993.
\end{abstract}

Keywords: Czech and Slovak Federative Republic; Slovak Republic; Czech Republic; research, elementary schools; secondary schools; citizenship; education

JEL Classifications: F50, F68, Z11

Reference to this paper should be made as follows: Lincényi, M., Mindár, M. 2021. Comparative analysis of the views and attitudes of elementary and secondary school pupils from the Czech Republic and Slovak Republic on the division of the Czech and Slovak Federative Republic (ČSFR). Insights into Regional Development, 3(1), 104-123. http://doi.org/10.9770/IRD.2021.3.1(6)

\footnotetext{
${ }^{*}$ This research was carried out in the framework of the project KEGA 003TnUAD-4/2018: Innovation of methodological letters for teachers of civic education from the point of view of prevention of manifestations of extremism and education for democratic citizenship.
}
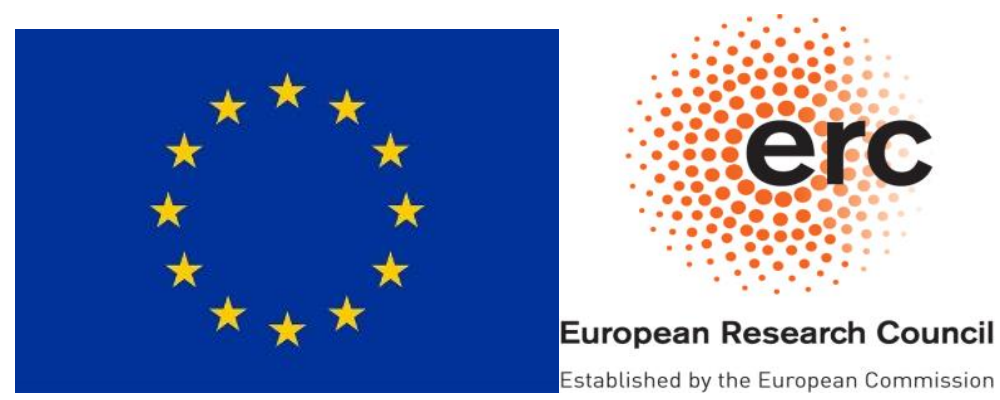
INSIGHTS INTO REGIONAL DEVELOPMENT

ISSN 2669-0195 (online) http://jssidoi.org/jesi/

2021 Volume 3 Number 1 (March)

http://doi.org/10.9770/IRD.2021.3.1(6)

Additional disciplines: political sciences

\section{Introduction}

The predecessor of the present independent and democratic Slovak Republic was the Slovak Socialist Republic, constituted by the Constitutional Act No. 143/1968 Coll. on the Czech-Slovak Federation, approved at the 28th National Assembly Session of 28 October 1968. Its solemn signature took place at the 50th anniversary of the adoption of the Declaration of the Slovak Nation (the so-called Martin Declaration) in the premises of the newly reconstructed Bratislava Castle, on 30 October 1968 (Rychlík 2015). This new national order entered into force on 1 January 1969. Czechoslovak Socialist Republic became a federative state composed of two republics of equal status: Czech Socialist Republic and Slovak Socialist Republic (Mindár 2018).

The post-November development in the Czecho-Slovak Republic brought about the restoration of democracy and the establishment of a pluralist political system. Slovak historian, Jozef Žatkuliak, states that this period of transformation of the social system and democracy building represented a significant milestone for the Slovak and Czech public in their mutual co-existence. Expressions of the Slovak and Czech post-November political representatives did not only convey the nation's national identity interests, but also economic ones, promoting the right of the nation to self-determination or national sovereignty, and equality with other States (Žatkuliak 2008). The restoration of democracy brought about marketing, as well as competition from political parties, with an aim to establish the foundations of pluralism and democratic principles of the State (Č́rsky 2018). "Political marketing is about applying and implementing a tactically thought-out election campaign by candidates or other political parties." (Čársky 2018, p. 120) Marketing communication has a significant impact in addressing the public (Kádeková et al. 2020), reflecting the shift in value orientation of the young generation after 1989 compared to the middle and older generation (Světlík and Bulanda 2019). At present, Slovak politicians are very well aware of the importance of mass-communication surveys, as the media have a significant share of the Internet in the establishment of the political scene, increasing the media, political and public agenda (Lincényi, Č́rsky 2020). Conversion of the joint Czecho-Slovak federation therefore only logically assumed transformation and drafting of laws. On their basis, a democratic federation was to be built, along with the creation of a genuine equal, equitable and mutually independent union of two national States, in the form of a federation based on their original sovereignty. According to Žatkuliak, the need to establish this condition was also justified by the fact that divergence of the unitary State into two national units in 1969 was only of a formal-institutional nature. Therefore, addressing national issues under democratic conditions proved to be necessary in the process of transformation. (Žatkuliak 2008)

"In a political environment, communication is a fundamental process of informing or influencing citizens by politicians or various institutions." (Čársky 2018, p. 121) The first serious post-November national identity crisis was the so-called Hyphen War. The new Czecho-Slovak federal president, Václav Havel, who supported the czecho-slovakistic federal tendencies, exercised his power of legislative initiative and, in his speech to the members of the Federal Assembly on 23 January 1990, proposed to change the national symbols, the name of the army, and delete the word "socialist" from the name of the State. According to his original idea, the new Czechoslovak emblem was to be composed of the characters of the Czech Republic, Moravia, and Slovakia. It was Slovak heraldists who rose in opposition to this proposal. They refused to give the Moravian she-eagle the same status as the Czech lion and the Slovak double cross. Despite this, Václav Havel initially expected his three proposals to be approved without difficulty by the members of the Federal Assembly. As there was no prior consultatio, and members of the federal parliament were not familiar with his proposals in advance, in a response to the President they stated that the republics must first agree on their own state symbols. Later, after consulting the leaders of the Czecho-Slovak Parliament, President Havel proposed a new variant called the Czecho-Slovak Republic. In the meantime, however, a group of Czech and Slovak federal members of parliament presented another alternative called Czechoslovak Federative Republic. The President's idea with the hyphen provoked a 
INSIGHTS INTO REGIONAL DEVELOPMENT

ISSN 2669-0195 (online) http://jssidoi.org/jesi/

2021 Volume 3 Number 1 (March)

http://doi.org/10.9770/IRD.2021.3.1(6)

wave of protests in a large part of the Czech public and Czech members of parliament. On the contrary, the Slovak community welcomed this proposal. At that time, president of the Federal Assembly, Alexander Dubček, publicly admitted that the whole Slovak parliamentary representation shared the President's proposal. In an emotive parliamentary debate, some of the Czech members of parliament started to defend vehemently the idea of Czechoslovakism, perceiving the hyphen as an insult to the Czech nation. They considered the name Czechoslovak Federative Republic as acceptable. On the contrary, the Slovak members of parliament saw the hyphen as a symbol of the refusal of Czechoslovakism. In the vote, the President's proposal with a hyphen was rejected by the votes of the Czech members. An alternative proposal, without a hyphen, passed in the House of the People, was not accepted thanks to the application of the principle of non-majority in the Slovak part of the House of Nations. Slovak institutions, including the Slovak National Council which came forward with its own proposal: Federation of Czecho-Slovakia, were also opposed to its adoption. The members of the Slovak National Council wanted to point out to the world that the Czecho-Slovak State was not just Czech State. The proposal of the Slovak Parliament immediately received broad support from the Slovak public. On the contrary, it was clearly rejected in the Czech Republic, since the name of the Czecho-Slovak Republic for the Czechs was reminiscent of the second post-Munich republic. On 29 March, following lengthy negotiations, Federal Assembly adopted the Constitutional Act No 81/1990 Coll. The name Czechoslovak Federative Republic was adopted. In practice, this meant that the Slovak version with the hyphen - Czecho-Slovak Federative Republic - was only an unofficial name. However, the Slovak side was not satisfied with this solution. In Slovakia, protests immediately started against the new name of the State and demonstrators for the first time voiced their preference of the idea of independence. Also, the Czech public became quite radicalised. Throughout various signing events, people called for the Federal Assembly to address more important things than a dispute over a hyphen, clearly rejected by most Czechs. Finally, the OF (Forum of Citizens) Czech members gave way and on 20 April 1990 the Federal Assembly adopted another Constitutional Act No. 101/1990 Coll., adopting the name Czech and Slovak Federative Republic. Czech national socialists refused to support this Act. In the meantime, they brought up the question of potential secession of Slovakia as the better alternative.

The second state-identification crisis was the so-called Process of Trenčianske Teplice. Prior to the first free elections of 1990, the Slovak government of national understanding, headed by Milan Čič, presented at the end of its term of office its own idea of Slovak-Czech relations within one common State. According to Anton Hrnka, this idea was fully in line with the vision of most of the Slovak society in that the new national union should be based on the primary sovereignty of the republics, followed by the derived, limited sovereignty of the federation. Following the first free elections (June 1990), this vision was presented to the Czech side by the new Slovak Prime Minister, Vladimir Mečiar, on 9 August 1990, in the town of Trenčianske Teplice, with the Czech Prime Minister, Petr Pithart, readily accepting his proposal for a new Competencies Act. In this respect, Hrnko further claims that only the subsequent negative reaction of the Czech public and the onset of aggressive klausean (of Václav Klaus) politics turned the initially spectacular project into a tear-off calendar. (Hrnko 2016). The Czechs wanted to preserve Czecho-Slovakia and perceived the federation as a redistribution of competencies. The concept of a functional federation endowed with certain powers such as foreign policy, defence, and currency, was considered as the main criterion. On the contrary, the Slovak side assumed that there were two states which merely delegated their powers to joint federal authorities. That is why the Czech Government and the Czech National Council discussed the situation that had arisen, without even excluding the possibility of the State's disintegration. Prior to the final vote on the Competencies Act, the Czech Government prepared a secret contingency plan for the event of a sudden breakdown of the CSFR. This plan essentially responded to the Slovak material which assessed Slovakia's position in the tear-off scenario. Final draft of the Competencies Act was approved by the Federal Assembly on 12 December 1990 as Constitutional Act No. 556/1990 Coll. In terms of its content, the Act severely restricted the powers of the federal authorities and removed the exclusive competence of the federation also in the field of foreign policy and defence. In practice, this meant that the creation of autonomous international treaties and the building of own armed forces of the republics was not ruled out. While 
INSIGHTS INTO REGIONAL DEVELOPMENT

ISSN 2669-0195 (online) http://jssidoi.org/jesi/

2021 Volume 3 Number 1 (March)

http://doi.org/10.9770/IRD.2021.3.1(6)

the Czech side considered the Competencies Law as the maximum measure, for Slovakia it was only the first step toward the ultimate goal of achieving the Czecho-Slovak joint State units. (Mindár 2018)

The third serious national identity crisis was the so-called Process of Milovy. This entailed a whole series of negotiations which started in spring 1991 and ended with a failed vote taken in the Slovak National Council Presidency in February 1992 on its outcome - The Agreement of Milovy. Anton Hrnko considered the Mílovy Agreement as a capitulation of the representatives of the then major political forces, VPN and KDH, against the Czech side's requirements for the project of future conditions within a joint State. He further argues

that the Agreement in its essence ensured supremacy and deprived the Slovak side of the last confederacy elements still left over from the Constitutional Act 143/1968 Coll. He opines that the Agreement was also demolishing, above all, the fundamental mechanism of equal to equal - the principle of no-majority. The year 1992 also saw the launch of legislative initiatives of President Václav Havel, together with the final drafting of the text of the Milovy Agreement on the principles of the national order of the joint State. Characteristics of the Milovy Agreement, its importance and content were the subject of discussions and disputes between the then coalition and the opposition in Slovakia, but mainly within the coalition itself. Final works were carried out in the joint commission of experts of the Czech National Council (ČNR) and Slovak National Council (SNR) for about a week in Milovy. The Commission completed its work on 8 February 1992. The Agreement envisioned a joint, two-chamber Parliament, which was to consist of a Chamber of Deputies and a Senate. The last dispute in the commission was the dispute over who was to sign the Agreement. The final proposal was that the Agreement was to be signed by the people of the Czech Republic and the people of the Slovak Republic. It was a fundamental change in the original political line of thought, originally shaped by the Slovak side and, in particular, by KDH. The then Slovak coalition representation thus made a clear political retreat from the original position of drafting a national agreement, through an inter-republic treaty, and finally to the drafting of an agreement between the peoples of both republics. Prior to the negotiations, the Chairman of the SNR, František Mikloško (from KDH political party), stated that it was essential that the principles we uphold be respected. He defended the Slovak position at the time, which they did not intend to compromise. And, referring to the outcome of the negotiation, he said again that this unity; however, was not absolute. He made it clear that not all political parties agreed on the matter. A surprisingly realistic view of the matter was presented by Federal Prime Minister, Marián Čalfa, who already believed that the final shape of the Czechoslovak state would be addressed only by the winners of the forthcoming elections (June 1992). On the other hand, shortly before the vote on the Agreement in the SNR Presidency, František Mikloško voiced his optimism that some political clubs, apart from the opposition, might also be willing to support the proposal, while the then coalition, with small exceptions, would be willing to vote in favour of the proposal. (Laluha 2016) On 11 February 1992 in Milovy, the agreed draft of the Agreement was approved by the ĆNR Presidency. (Stein 2000) On 12 February 1992, Presidency of the SNR did not approve the draft, ending with a 10:10 split vote. (Mindár 2018a) Contrary to the statement by František Mikloško, as many as four members from KDH, i.e. the majority (the total number of SNR Presidency members was six), voted against. Vladimir Kmet', František Javorský, Ján Klepáč, and Anton Hykisch, as well as Milan Ftáčnik from SDL' (Slovak Democratic Left), and Milan Zemko, an independant member of parliament representing the Civil Democratic Union-VPN. (Laluha 2016) With the Milovy Agreement draft, both republics' national councils exhausted their options to agree on a model acceptable to both negotiating parties. This vote within the SNR Presidency indicated a profound contradiction not only between Slovak politicians, but also in the society as such. Thus, the Milovy Agreement has become the biggest political disagreement between Slovak and Czech politicians since November 1989. The fundamental differences of opinion of the political elites on both sides have shown different perceptions of what a joint state should look like. This fact also predetermined the positions of political players after the elections in June 1992. (Mindár 2018)

As early as the beginning of 1991, according to Anton Hrnko, discussions on a possible declaration of sovereignty of the Slovak Republic were now taking place in the form of direct implementation. In March 1991, SNS submitted its draft Constitution of the Slovak Republic, which no longer considered the existence of a federation. 
INSIGHTS INTO REGIONAL DEVELOPMENT

ISSN 2669-0195 (online) http://jssidoi.org/jesi/

2021 Volume 3 Number 1 (March)

http://doi.org/10.9770/IRD.2021.3.1(6)

In March-April 1991, the first proposal for the declaration of sovereignty of the Slovak Republic was submitted for negotiation in the Slovak Parliament. According to Hrnko, the idea was gradually also adopted by HZDS, alongside the with SNS. It also made its way into KDH, SDL, and the Green Party. In his view, its support had grown to such an extent that, at the SNR session in May 1992, it was already supported by most of the Members elected in the first free elections of 1990. (Hrnko 2017).

Negotiations between HZDS and the winning Czech party (ODS) were ultimately geared toward a constitutional and peaceful separation of the Czech and Slovak Republic into two separate States - the Slovak Republic and the Czech Republic. This took place at the Federal Assembly session through the adoption of the Constitutional Act on the dissolution of the ČSFR No. 542/1992 on 25 November 1992. The original intention of HZDS about the entry of the Slovak Republic as a sovereign state into the Union of States with the Czech Republic did not appeal to the Czech ODS whose sole objective was the creation of the so-called functional Federation, or two independant States. According to Pavol Hrivík, the idea of disintegration of the ČSFR was not originally accepted by the world powers, nor by the surrounding States with great enthusiasm. The main reason for their original opinion was, in his view, the difficult and tense situation in Eastern Europe, particularly in the former Yugoslavia. At that time, of no lesser importance were facts linked to minority problems, also present in some EU Member States: the Basques in Spain, the Corsicans in France, Northern Irelanders and Scots in the United Kingdom, or the Walloons in Belgium. However, the agreement of Slovaks and Czechs on the constitutional, civilized and peaceful division of their common state was finally accepted by the world with great understanding and recognition. Finally, majority of States expressed in advance their willingness to internationally recognise the two successor States once they would be independent. According to Hrivík, the whole period after January 1993 showed that the division of the Czecho-Slovak Federation was the right historical act. He claims that the former federation would never have been able to secure the current above-standard relations between the Slovak and Czech peoples. (Hrivík 2012) In the introductory part of the Preamble to the Constitution of the Slovak Republic, Slovak Republic claims the legacy of St. Cyril and Methodius. It is interesting that throughout the whole existence of the Hungarian kingdom, our ancestors managed to preserve the Cyril-Methodius tradition for future generations. Karol Janas believes it was not common at that time, due to the dominance of the Cult of Mary in Slovakia. Besides, the Cyril-Methodius tradition was perceived as negative by the then Hungarian ecclesiastical as well as secular authorities. They saw it as the promotion of foreign and unknown saints in Hungary. (Janas 2019) Slovak Republic also played an important role in the process of enlargement of the European Union to include the Western Balkans. (Janas 2017) On the other hand, European Union is facing various challenges today. The process of European integration therefore needs to be modernized, particularly by reducing democratic deficit and the impact of unilateral interests and rare "modernistic" tendencies of the European globalizing elites. (Hrivík 2017) Democratic deficit in the EU is a complex phenomenon that has various causes and manifestations. (Hrivík, Mindár 2018) According to Marcel Lincényi's survey conducted in the first quarter of 2017, 1398 respondents, who were representative of the adult population in terms of sex, age, education and regions, showed that more than half of the Slovaks interviewed believe that the future of the common European Union will exceed 10 years. More than a third of the respondents (36\%) think that the EU will last beyond 2030, while another quarter of the respondents (24\%) see the common EU last until 2030. (Lincényi 2018)

\section{Methodology}

The paper's main objective was a comparative analysis into the present views and knowledge of pupils from selected elementary and secondary schools in the Czech and Slovak Republics on the issue of division of the Czech and Slovak Federative Republic (ČSFR) into two independent States.

The secondary research objective was to identify similarities and differences in the views and knowledge of selected elementary and secondary school pupils in the Czech Republic and Slovakia on the division of the Czech and Slovak Federative Republic into two independent States. 
INSIGHTS INTO REGIONAL DEVELOPMENT

ISSN 2669-0195 (online) http://jssidoi.org/jesi/

2021 Volume 3 Number 1 (March)

http://doi.org/10.9770/IRD.2021.3.1(6)

In the planning and design phases of research, we have identified the following research questions:

RQ1: What was the share of Slovak pro-national and patriotic associations since November 1989 in shaping the public toward the idea of an independent Slovak Republic?

Explanation of RQ1: As to the first research question, we examined the knowledge and views of pupils from selected elementary and secondary schools of the Zlín self-governing region (Czech Republic) and the Trenčín self-governing region (Slovak Republic) on progressive shaping of the independent and democratic Slovak Republic after 1989. We have therefore decided to create three questionnaire items (questions): "Do you think that the pro-national Slovak intelligence shaped the members of individual political parties and movements toward the creation of the independent Slovak Republic?". "Would you say that the Czech nation did not create equal conditions for coexistence with the Slovak nation throughout the whole existence of the Czechoslovak Republic?". "Do you agree that it was the new democratic establishment after November 1989 that created preconditions for gradual dissolution of the Czech and Slovak Federative Republic?'

RQ2: To what extent did the then Czech political scene have a stake in the dissolution of the Czech and Slovak Federative Republic?

Explanation of RQ2: As to the second research question, we examined, among the pupils of selected elementary and secondary schools of the Zín self-Governing Region (Czech Republic) and the Trenčín self-governing Region (Slovak Republic), whether they thought that it was predominantly the Czech lay public who had played the major role in the dissolution of the Czech and Slovak Federative Republic. (ČSFR) Therefore, we decided to ask the following three questionnaire items (questions) as follows: "Do you think that the Czech political and lay public was not able to understand the Slovak requirements leading to the equal treatment of the Slovak nation within the Czech and Slovak Federative Republic?", "Do you think that Slovakia was an economic obstacle within the Czech and Slovak Federative Republic?", "Do you think that the division of the Czech and Slovak Federative Republic was promoted mainly by the Czech political public?"

RQ3: Was the creation of the independent Slovak Republic and Czech Republic the culmination of the national-emancipation efforts of both nations?

Explanation of RQ3: In the third research question, we asked the pupils of selected elementary and secondary schools of the Zlin self-governing region (Czech Republic) and the Trenčín self-governing region (Slovak Republic) who did not experience the division of the Czech Republic and Slovakia into two separate States (Slovak Republic and Czech Republic) about their perception of the independent Slovak Republic and Czech Republic today. We have therefore created five questionnaire items (questions): "Do you agree with the view that the division of the Czech and Slovak Federative Republic led to a gradual improvement of the mutual SlovakCzech and Czech-Slovak relations?", "Do you agree with the statement that the Slovaks gradually formed themselves into a state-owned nation during the existence of the Czech-Slovak Republic?", "Do you think, That the creation of an independent Slovak Republic has brought peace to stability in the Central European Area?", and the only open question: "How do you perceive the division of the Czech and Slovak Federative Republic now, after more than a quarter of a century?", Ccan you imagine that the Slovak and Czech Republic were to be united in one single state again in the future?"

We carried out our research in a quantitative manner. We used questionnaire as the main research method to collect data, containing 11 quantitative questionnaire items. Collection of data was carried out in the second quarter of 2020, on a research sample of 850 respondents. (of which 438 were from the Czech Republic and 412 from the Slovak Republic) 
INSIGHTS INTO REGIONAL DEVELOPMENT

ISSN 2669-0195 (online) http://jssidoi.org/jesi/

2021 Volume 3 Number 1 (March)

http://doi.org/10.9770/IRD.2021.3.1(6)

As a research sample we selected pupils aged 13 to 20 in selected elementary and secondary schools of the Zlín self-governing Region (Czech Republic) and the Trenčín self-governing Region. (Slovak Republic) 438 responses were received from the Zlín self-governing region, comprising 223 women and 215 men. (Secondary School of Luhacovice, Secondary Vocational School of Valašské Klobuky, Gymnasium of Jan Pivečka in Slavičín, Elementary School of Slavičín - Vlára, Elementary School and Kindergarten of Nedašov, Elementary School of Brumov-Bylnice, Elementary School of Gabry a Málinky Štítná nad Vláří) 412 respondents, of which 296 were women and 116 were men. (Gymnasium of Dubnica nad Váhom, Gymnasium of Púchov, Business Academy of Dr. Milan Hodza in Trenčín, Business Academy in Povazská Bystrica, Elementary School of Nová Dubnica, Elementary School of Vel'komoravská 12 in Trenčín, Elementary School with kindergarten of Václav Mitúch of Horné Srnie, Elementary School of Janko Pala 2, Nemšová, Elementary School with kindergarten of Hugolin Gavlovič in Pruské, Elementary School of Medňanská Ilava) Collection of data took place from February 2020 to June 2020. The questionnaire was drawn up in Slovak and Czech languages and consisted of ten multiple-choice questions of three options (Yes-Agree, No-Disagree, Cannot assess) and one open question in which respondents were free to express their point of view.

Using the method of fixation and data sorting, we have first verified the correct procedure for filling out our questionnaires. We then proceeded to the counting, scaling and selection of data, which we statistically classified into eleven tables. Finally, using the method of interpretation and exploratory analysis, we have evaluated the results of the research carried out.

\section{Analysis of results}

As part of the first question of the questionnaire, we asked whether pupils thought that the pro-national Slovak intelligence helped shape members of individual political parties and movements toward the creation of a separate Slovak Republic. A greater number of positive answers to this question came from the Slovak Republic. In our view, this is because in the Czech Republic and the Slovak Republic exist differences of opinion on the nationalemancipation process of the Slovak nation in one common State. The fact that up to $61.9 \%$ of pupils answered "Cannot assess" in the Czech Republic makes us assume that the current Czech youth is totally unaware of the real reasons and causes of Slovakia's gradual independence from the dominant Czech nation. Respondents in the Slovak Republic replied in a similar manner. Even though $41.3 \%$ think that the creation of the independent and democratic Slovak Republic was initiated by pro-national Slovak intelligence, an absolute majority of 52,4\% could not adequately answer our question. In our view, our elementary and secondary schools are not sufficiently attentive to this historical event. See Table 1 and Chart 1 for more information.

Table 1 Do you think that the pro-national Slovak intelligence shaped the members of individual political parties and movements toward the creation of a separate Slovak

Republic?

\begin{tabular}{|c|c|c|c|c|c|c|c|c|}
\hline & \multicolumn{4}{|c|}{ Slovak Republic } & \multicolumn{4}{|c|}{ Czech Republic } \\
\hline & \multicolumn{3}{|c|}{ Number of respondents } & \multirow{2}{*}{$\%$} & \multicolumn{3}{|c|}{ Number of respondents } & \multirow{2}{*}{$\%$} \\
\hline & Women & Men & Altogether & & Women & MEN & Altogether & \\
\hline Yes & 121 & 49 & 170 & 41.3 & 63 & 61 & 124 & 28.3 \\
\hline No & 14 & 12 & 26 & 6.3 & 15 & 28 & 43 & 9.8 \\
\hline Not know & 161 & 55 & 216 & 52.4 & 145 & 126 & 271 & 61.9 \\
\hline Altogether & 296 & 116 & 412 & 100 & 223 & 215 & 438 & 100 \\
\hline
\end{tabular}

Source: Processed based on the results of own research. 
Chart 1 Do you think that the pro-national Slovak intelligence shaped the members of individual political parties and movements toward the creation of a separate Slovak Republic?

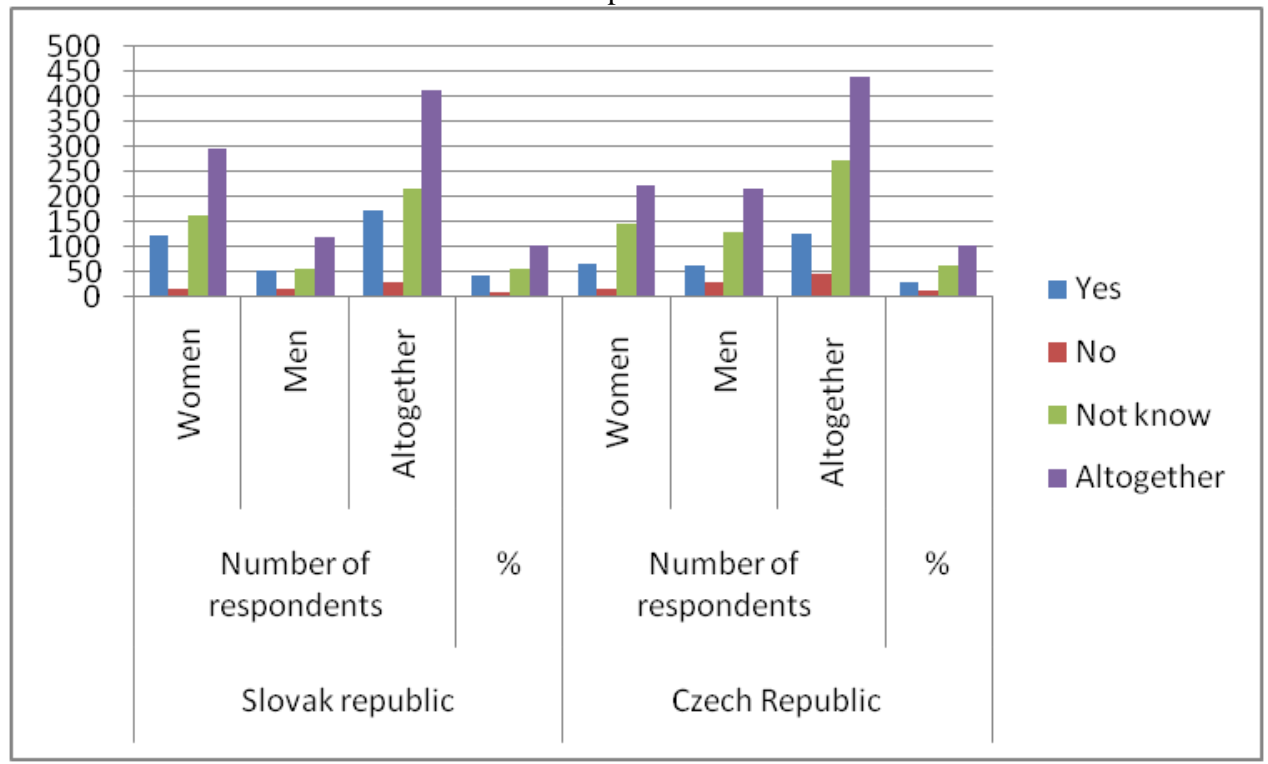

Source: Processed on the basis of the results of own research.

In the second question we asked the respondents whether they agreed that the Czech nation did not create equal conditions for coexistence with the Slovak nation throughout the whole existence of the Czech-Slovak Republic. In Slovakia, 58,0\% of respondents agreed to this claim. In contrast, as many as $61,4 \%$ of the respondents in the Czech Republic strongly disagreed. On the basis of these results, we can clearly confirm that in view of the different views on the nature of the organization of relations between the Slovak and Czech people after November 1989 in the former Czecho-Slovak Republic, a peaceful and constitutional division of the CzechoSlovak Federation into two separate States (Slovak Republic, Czech Republic) represented the only possible and correct course. For more information see Table 2 and Chart 2.

Table 2 Do you agree that the Czech nation throughout the whole existence of the Czecho-Slovak Republic did not create equal conditions of coexistence with the Slovak nation?

\begin{tabular}{|c|c|c|c|c|c|c|c|c|}
\hline & \multicolumn{4}{|c|}{ Slovak Republic } & \multicolumn{4}{|c|}{ Czech Republic } \\
\hline & \multicolumn{3}{|c|}{ Number of respondents } & \multirow[b]{2}{*}{$\%$} & \multicolumn{3}{|c|}{ Number of respondents } & \multirow[b]{2}{*}{$\%$} \\
\hline & Women & Men & Altogether & & Women & Men & Altogether & \\
\hline Agree & 173 & 66 & 239 & $\mathbf{5 8 . 0}$ & 27 & 32 & 59 & $\mathbf{1 3 . 5}$ \\
\hline Disagree & 70 & 25 & 95 & 23.1 & 144 & 125 & 269 & 61.4 \\
\hline Not know & 53 & 25 & 78 & 18.9 & 52 & 58 & 110 & 25.1 \\
\hline Altogether & 296 & 116 & 412 & 100 & 223 & 215 & 438 & 100 \\
\hline
\end{tabular}

Source: Processed based on the results of own research. 


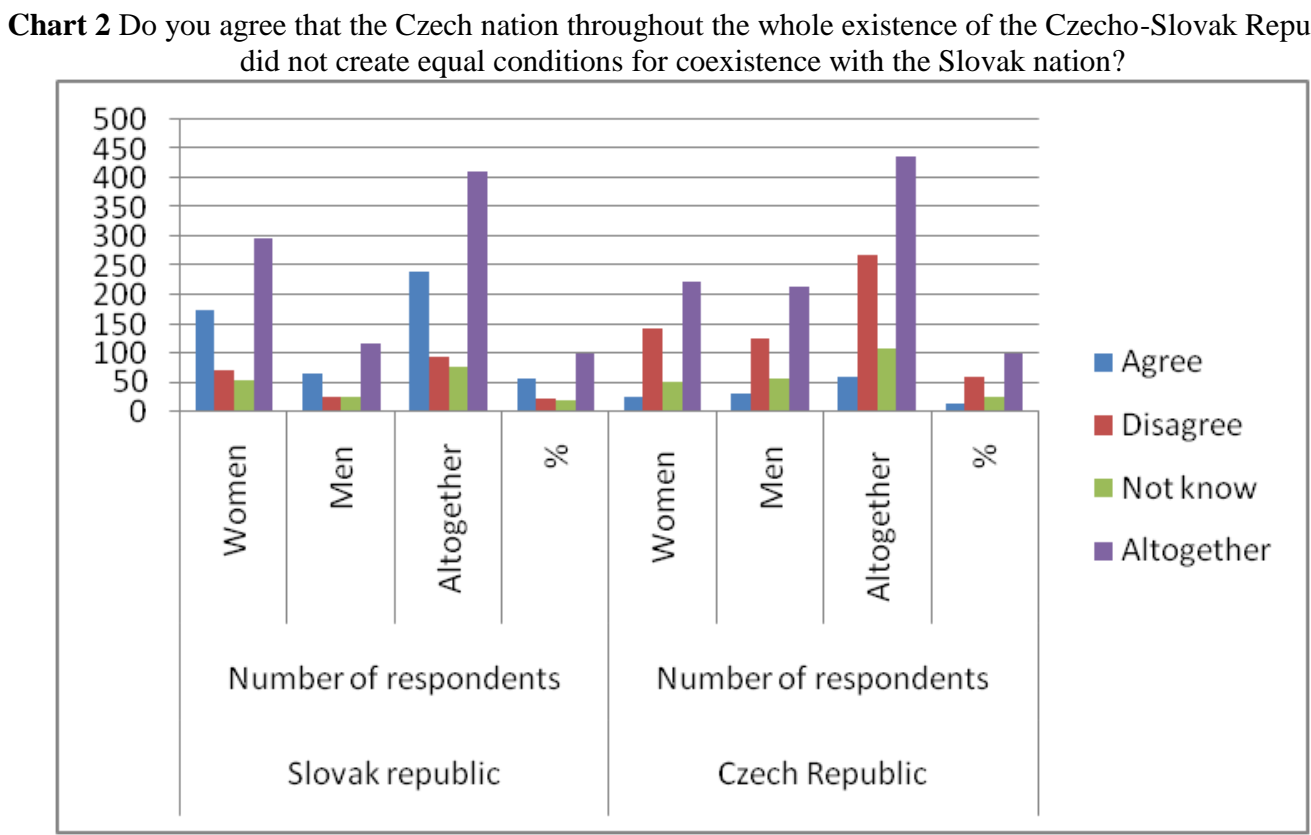

Source: Processed on the basis of the results of own research.

In the third question, we asked the pupils whether they agreed that the new democratic establishment after November 1989 created preconditions for gradual dissolution of the Czech and Slovak Federative Republic. This claim was accepted by a large proportion of Czech as well as Slovak respondents. The gradual withdrawal of the Soviet Union from the Central European arena opened possibilities for a gradual creation of an independent and democratic Slovak Republic. Despite numerous conflicts between the Slovak and Czech nations, they were fortunately not dealt with by military means, as was the case of the former Yugoslavia. Constitutional and peaceful split-up of the Czech and Slovak Federative Republic (ČSFR) into two separate States (Slovak Republic, Czech Republic) at the Prague Federal Assembly has up to date been given as an example for other European and the world nations seeking autonomy. (Scots, Catalans) For more information see Table 3 and Chart 3.

Table 3 Do you agree that a new democratic establishment after November 1989 created preconditions for a gradual dissolution of the Czech and Slovak Federative Republic?

\begin{tabular}{|c|c|c|c|c|c|c|c|c|}
\hline & \multicolumn{4}{|c|}{ Slovak Republic } & \multicolumn{4}{|c|}{ Czech Republic } \\
\hline & \multicolumn{3}{|c|}{ Number of respondents } & \multirow[b]{2}{*}{$\%$} & \multicolumn{3}{|c|}{ Number of respondents } & \multirow[b]{2}{*}{$\%$} \\
\hline & Women & Men & Altogether & & Women & Men & Altogether & \\
\hline Agree & 112 & 54 & 166 & 40.3 & 88 & 97 & 185 & 42.2 \\
\hline Disagree & 40 & 16 & 56 & 13.6 & 36 & 50 & 86 & 19.7 \\
\hline Not know & 144 & 46 & 190 & 46.1 & 99 & 68 & 167 & 38.1 \\
\hline Altogether & 296 & 116 & 412 & 100 & 223 & 215 & 438 & 100 \\
\hline
\end{tabular}

Source: Processed based on the results of own research. 
Chart 3 Do you agree that a new democratic establishment after November 1989 created preconditions for a gradual dissolution of the Czech and Slovak Federative Republic?

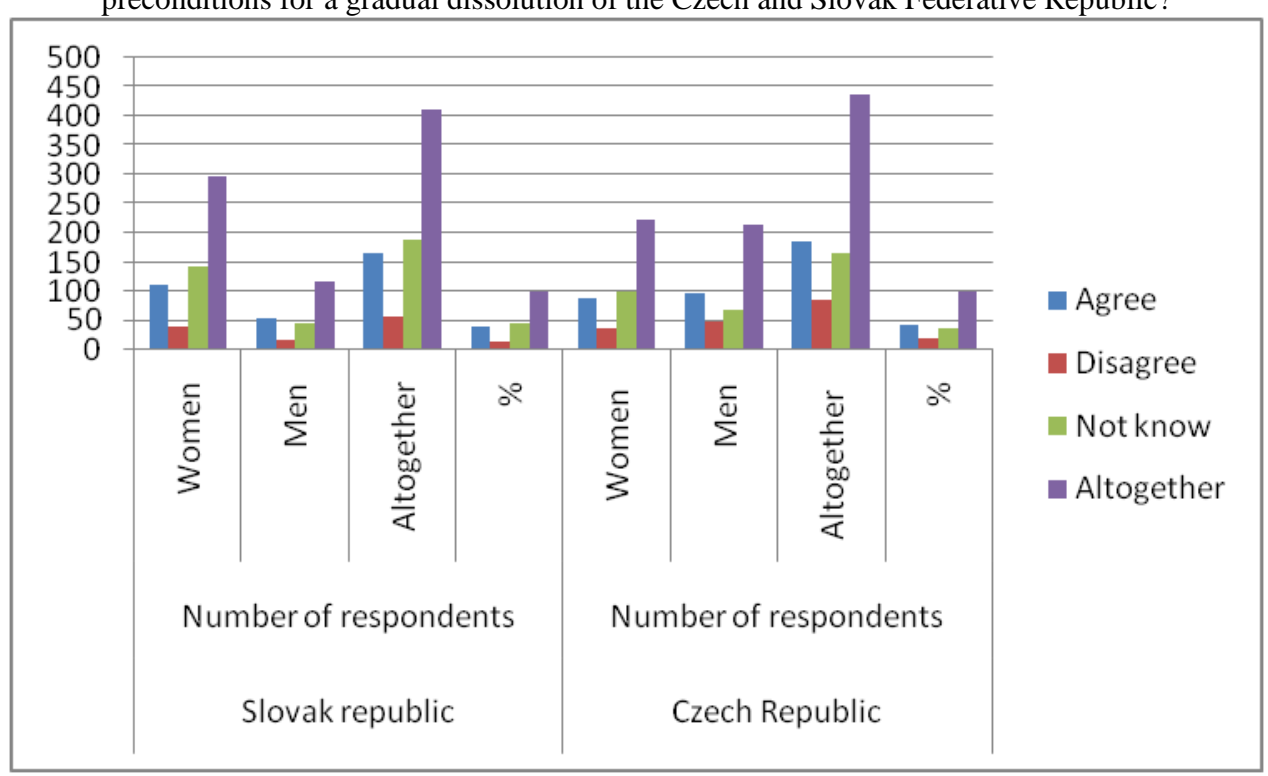

Source: Processed on the basis of the results of own research.

In the fourth question, we asked whether they thought that the Czech political and lay public were not able to sufficiently understand the Slovak requirements leading to the equal treatment of the Slovak nation within the Czech and Slovak Federative Republic. Up to 48,3\% of respondents responded positively to this question in the Slovak Republic. On the contrary, in the Czech Republic, 34,9\% of the responses to the same question were positive. Here too, different views on our common Czech-Slovak history have been manifested. While most Slovaks considered the Czecho-Slovak Republic as a joint State of the Czech and Slovak nation, most Czechs considered it rather a Czech state extended to the Slovak territory. The fact that up to $23,5 \%$ of respondents in the Czech Republic think that the Czech political and lay public were not able to sufficiently understand the Slovak requirements leading to the equal treatment of the Slovak nation within the Czech and Slovak Federative Republic (CSFR) is due to the fact that our research was limited only to the territory of the Zlín self-governing region, which is part of the historical territory of Moravia. If we were to concentrate our research on all the regions of the Czech Republic, the results would be dramatically different. In our view, approximately $15 \%$ of Czech respondents would be in favour of a "Yes" answer. For more information see Table 4 and Chart 4.

Table 4 Do you think that the Czech political and lay public were not sufficiently able to

\begin{tabular}{|c|c|c|c|c|c|c|c|c|}
\hline & \multicolumn{4}{|c|}{ Slovak Republic } & \multicolumn{4}{|c|}{ Czech Republic } \\
\hline & \multicolumn{3}{|c|}{ Number of respondents } & \multirow{2}{*}{$\%$} & \multicolumn{3}{|c|}{ Number of respondents } & \multirow{2}{*}{$\%$} \\
\hline & Women & Men & Altogether & & Women & Men & Altogether & \\
\hline Yes & 144 & 55 & 199 & 48.3 & 48 & 55 & 103 & 23.5 \\
\hline No & 39 & 20 & 59 & 14.3 & 83 & 70 & 153 & 34.9 \\
\hline Not know & 113 & 41 & 154 & 37.4 & 92 & 90 & 182 & 41.6 \\
\hline Altogether & 296 & 116 & 412 & 100 & 223 & 215 & 438 & 100 \\
\hline
\end{tabular}

Source: Processed based on the results of own research. 
Chart 4 Do you think that the Czech political and lay public were not sufficiently able to understand the Slovak requirements leading to the equal treatment of the Slovak nation within the Czech and Slovak Federative Republic?

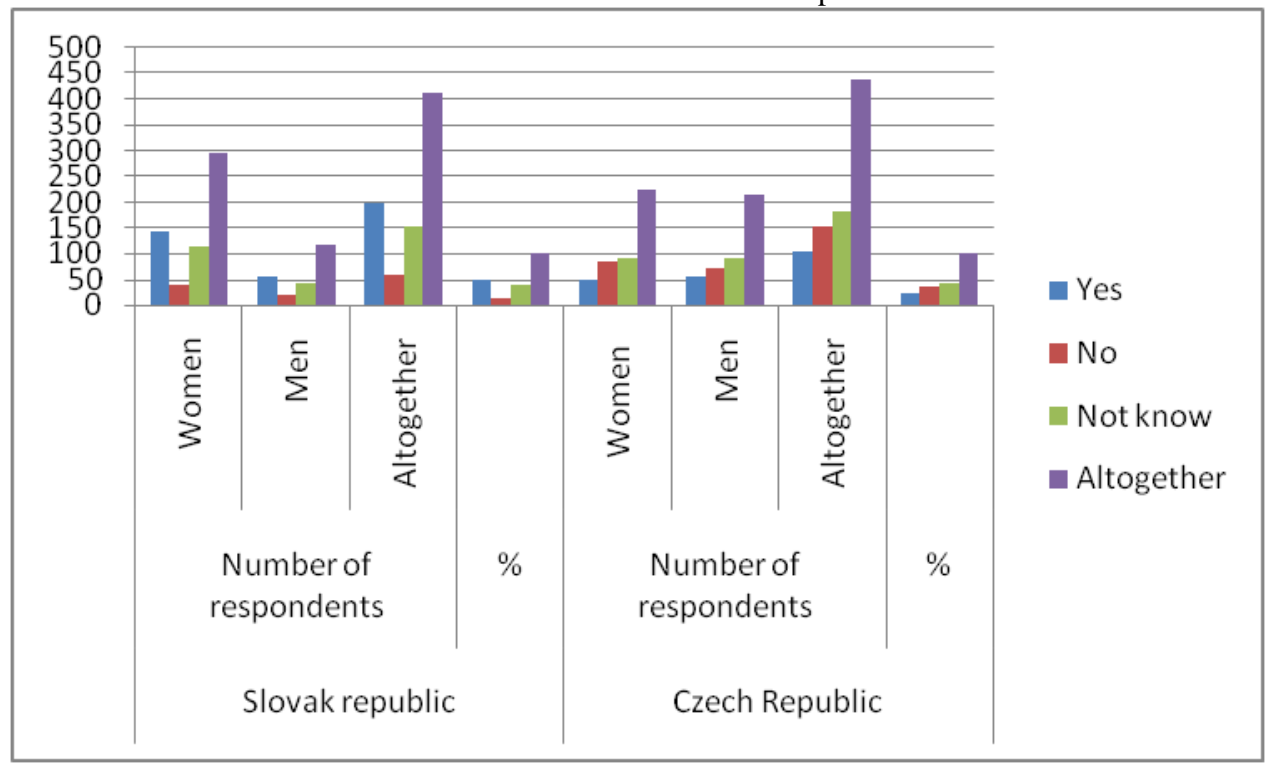

Source: Processed on the basis of the results of own research.

In the fifth question, we asked the pupils about their view on Slovakia's being an economic obstacle within Czecho-Slovakia. Most Slovak and Czech respondents responded negatively to this question. In our view, here too, if we were to target our research to all regions of the Czech Republic as well as the Slovak Republic, or if we were to address older age groups, the results would be dramatically different. For more information see Table 5 and Chart 5.

Chart 5 Do you think that Slovakia was an economic obstacle within Czecho-Slovakia?

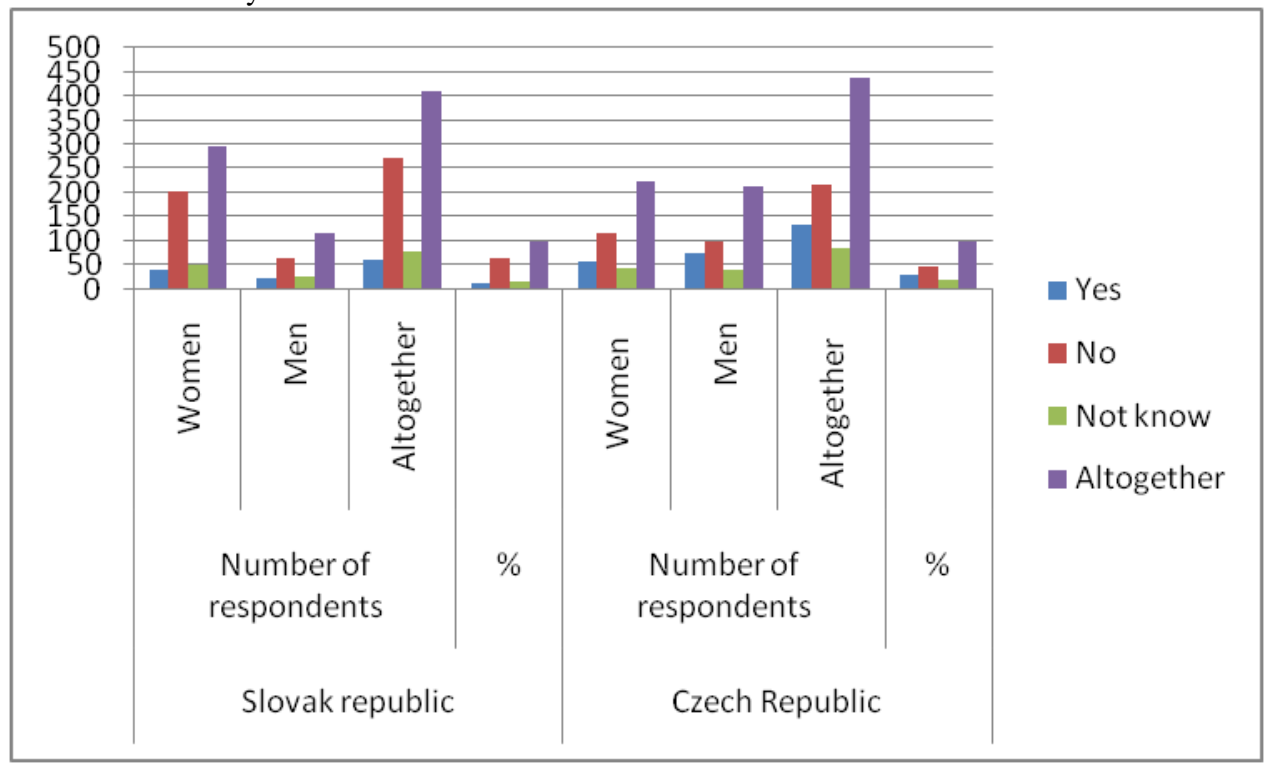

Source: Processed based on the results of own research. 
In the sixth question, we asked the pupils whether they thought that the split-up of the Czech and Slovak Federative Republic was mainly promoted by the Czech political public. Respondents in the Slovak Republic and the Czech Republic replied to this question in a dramatically different manner. Just like in previous questions, if we targeted our research to all ages and regions in the Slovak Republic and the Czech Republic, the results would be dramatically different. For more information see Table 6 and Chart 6.

Table 6 Do you think that the split-up of the Czech and Slovak Federative Republic

was promoted by the Czech political public in particular?

\begin{tabular}{|c|c|c|c|c|c|c|c|c|}
\hline & \multicolumn{4}{|c|}{ Slovak Republic } & \multicolumn{4}{c|}{ Czech Republic } \\
\cline { 2 - 4 } & \multicolumn{3}{|c|}{ Number of respondents } & \multirow{2}{*}{$\%$} & \multicolumn{3}{c|}{ Number of respondents } & \multirow{2}{*}{$\%$} \\
\cline { 2 - 5 } \cline { 6 - 8 } & Women & Men & Altogether & & Women & Men & Altogether & \\
\hline Yes & 94 & 32 & 126 & $\mathbf{3 0 . 6}$ & 52 & 24 & 76 & $\mathbf{1 7 . 4}$ \\
\hline No & 123 & 49 & 172 & $\mathbf{4 1 . 8}$ & 101 & 144 & 245 & $\mathbf{5 5 . 9}$ \\
\hline Not know & 79 & 35 & 114 & $\mathbf{2 7 . 6}$ & 70 & 47 & 117 & $\mathbf{2 6 . 7}$ \\
\hline Altogether & 296 & 116 & 412 & $\mathbf{1 0 0}$ & 223 & 215 & 438 & $\mathbf{1 0 0}$ \\
\hline
\end{tabular}

Chart 6 Do you think that the split-up of the Czech and Slovak Federative Republic was promoted by the Czech political public in particular?

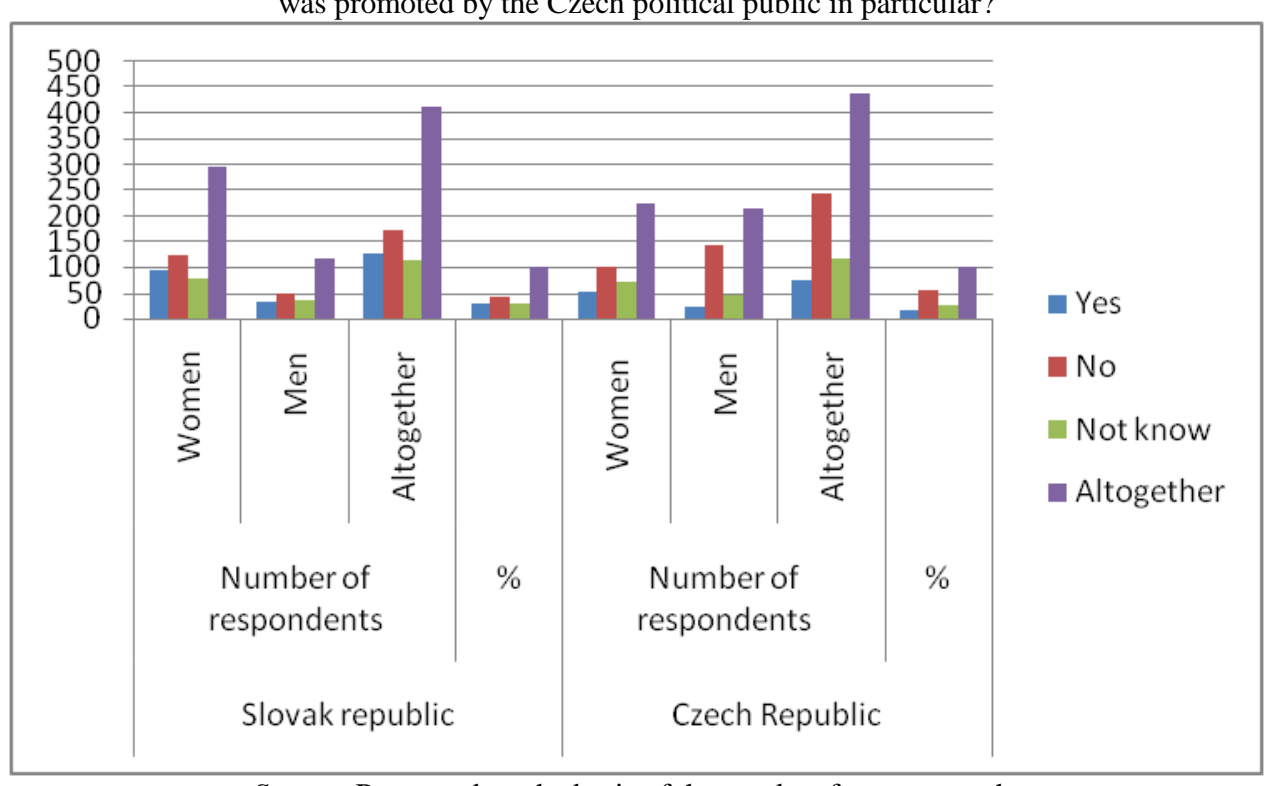

Source: Processed on the basis of the results of own research.

In the seventh question, we asked whether they agreed that the division of the Czech and Slovak Federative Republic led to a gradual improvement in mutual Slovak-Czech and Czech-Slovak relations. Most Slovak and Czech respondents agreed with this claim. This fact only proves that the division of the Czech and Slovak Federative Republic (ČSFR) into two separate States (Slovak Republic, Czech Republic) was the right decision for both nations. For more information see Table 7 and Chart 7. 
INSIGHTS INTO REGIONAL DEVELOPMENT

ISSN 2669-0195 (online) http://jssidoi.org/jesi/

2021 Volume 3 Number 1 (March)

http://doi.org/10.9770/IRD.2021.3.1(6)

Table 7 Do you agree with the view that the separation of the Czech and Slovak Federative Republic led to a gradual improvement in mutual Slovak-Czech and Czech-Slovak

relations?

\begin{tabular}{|c|c|c|c|c|c|c|c|c|}
\hline & \multicolumn{4}{|c|}{ Slovak Republic } & \multicolumn{4}{|c|}{ Czech Republic } \\
\hline & \multicolumn{3}{|c|}{ Number of respondents } & \multirow{2}{*}{$\%$} & \multicolumn{3}{|c|}{ Number of respondents } & \multirow{2}{*}{$\%$} \\
\hline & Women & Men & Altogether & & Women & Men & Altogether & \\
\hline Agree & 149 & 48 & 197 & 47.8 & 118 & 97 & 215 & 49.1 \\
\hline Disagree & 75 & 34 & 109 & 26.5 & 58 & 68 & 126 & 28.8 \\
\hline Not know & 72 & 34 & 106 & 25.7 & 47 & 50 & 97 & 22.1 \\
\hline Altogether & 296 & 116 & 412 & 100 & 223 & 215 & 438 & 100 \\
\hline
\end{tabular}

Chart 7 Do you agree with the view that the separation of the Czech and Slovak Federative Republic led to a gradual improvement in mutual Slovak-Czech and Czech-Slovak relations?

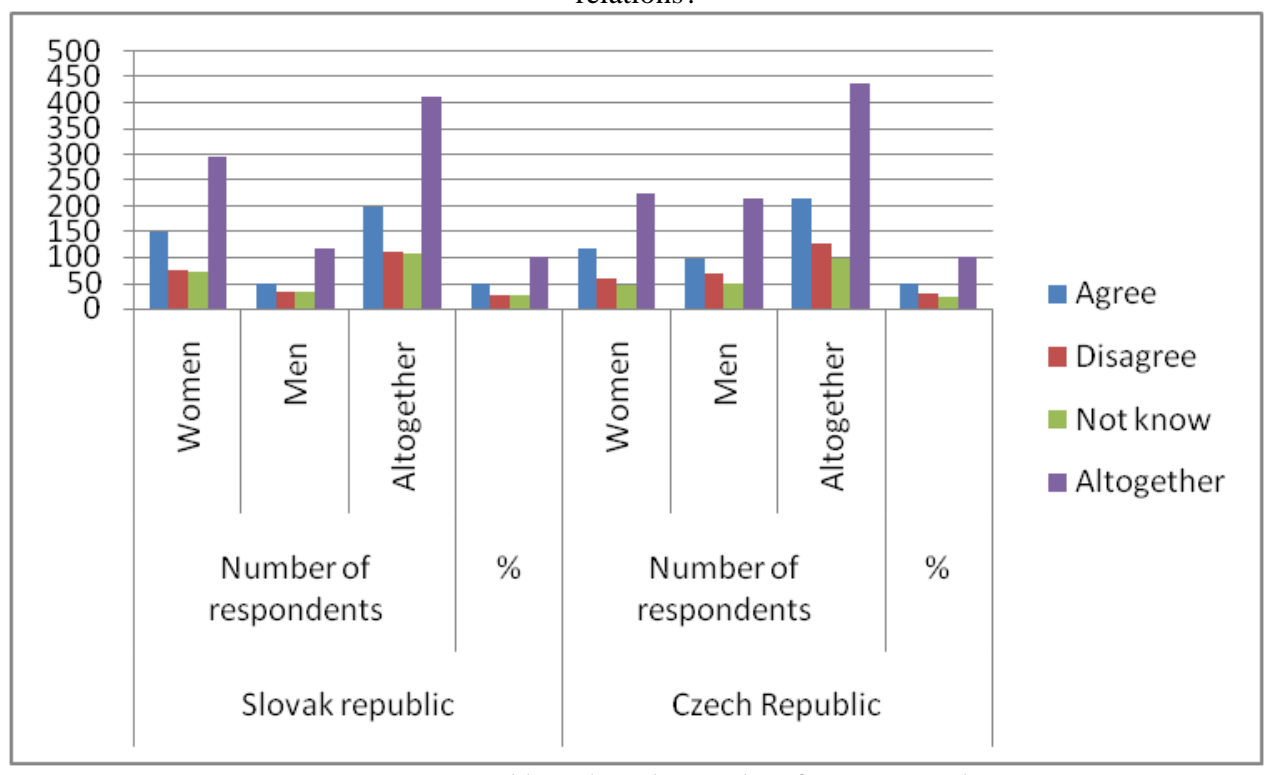

Source: Processed based on the results of own research.

In the eighth question, we asked whether the pupils agreed with the claim that during the existence of the CzechoSlovak Republic, Slovaks gradually evolved into a State-building nation. More than a half of the respondents in the Slovak Republic responded affirmatively to this question. This fact only shows that most Slovaks saw the former Czecho-Slovak Republic as a joint State of equal and self-determined nations of Czechs and Slovaks. Unfortunately, most Czechs have never seen Slovaks as an equal partner throughout almost the whole existence of the Republic. This also contributed to the fact that many respondents in the Czech Republic were not able to comment on this question. See Table 8 and Chart 8 for more information. 
INSIGHTS INTO REGIONAL DEVELOPMENT

ISSN 2669-0195 (online) http://jssidoi.org/jesi/

2021 Volume 3 Number 1 (March)

http://doi.org/10.9770/IRD.2021.3.1(6)

Table 8 Do you agree with the claim that Slovaks, while living in the Czecho-Slovak Republic, gradually evolved into a state-building nation?

\begin{tabular}{|c|c|c|c|c|c|c|c|c|}
\hline & \multicolumn{4}{|c|}{ Slovak Republic } & \multicolumn{4}{c|}{ Czech Republic } \\
\cline { 2 - 6 } & \multicolumn{3}{|c|}{ Number of respondents } & \multirow{2}{*}{$\%$} & \multicolumn{3}{c|}{ Number of respondents } & \multirow{2}{*}{$\%$} \\
\cline { 2 - 6 } \cline { 6 - 9 } & Women & Men & Altogether & & Women & Men & Altogether & \\
\hline Agree & 162 & 62 & 224 & $\mathbf{5 4 . 4}$ & 72 & 83 & 155 & $\mathbf{3 5 . 4}$ \\
\hline Disagree & 31 & 15 & 46 & $\mathbf{1 1 . 1}$ & 46 & 42 & 88 & $\mathbf{2 0 . 1}$ \\
\hline Not know & 103 & 39 & 142 & $\mathbf{3 4 . 5}$ & 105 & 90 & 195 & $\mathbf{4 4 . 5}$ \\
\hline Altogether & 296 & 116 & 412 & $\mathbf{1 0 0}$ & 223 & 215 & 438 & $\mathbf{1 0 0}$ \\
\hline
\end{tabular}

Chart 8 Do you agree with the claim that Slovaks, while living in the Czecho-Slovak Republic, gradually evolved into a state-building nation?

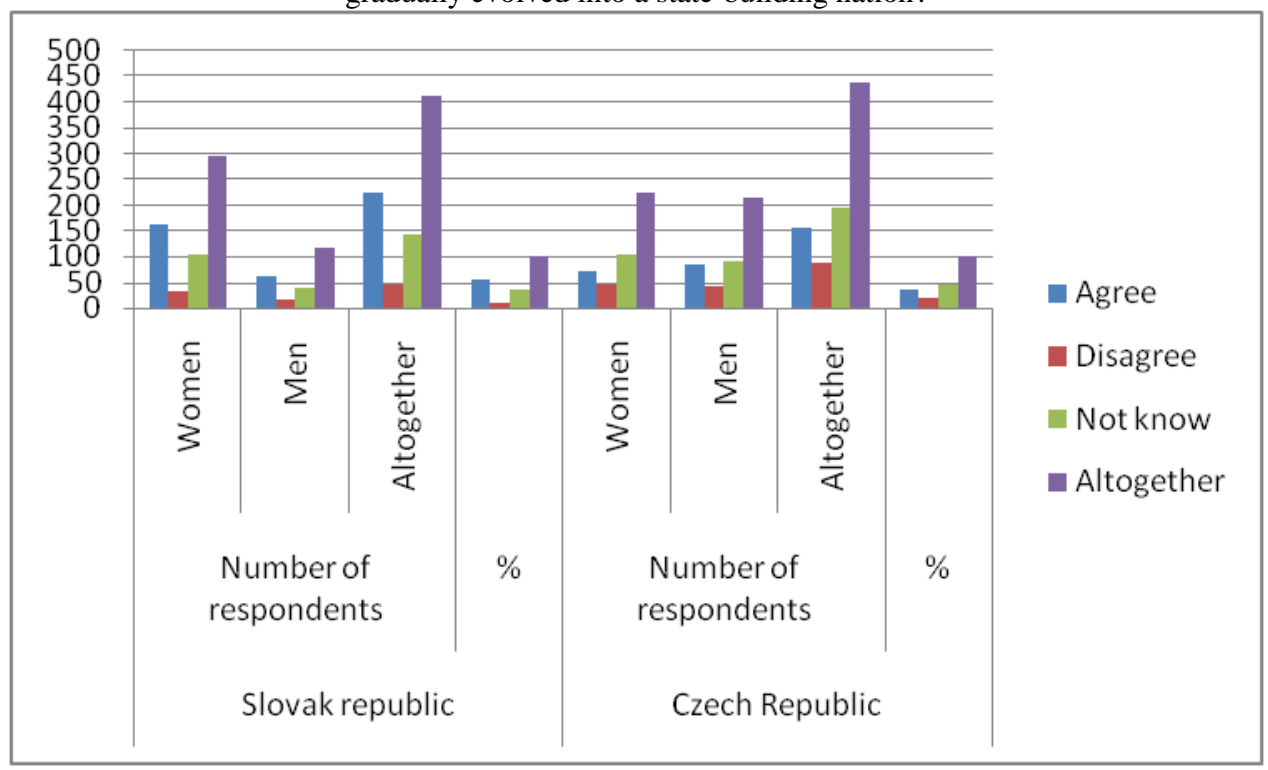

Source: Processed based on the results of own research.

In the ninth question, we asked whether pupils thought that the creation of an independent Slovak Republic brought peace and stability within the Central European area. Most pupils in the Slovak Republic and the Czech Republic replied affirmatively to this question. On the other hand, a large proportion of them in both countries were not able to express themselves. As mentioned above, the split-up of the Czech and Slovak Federative Republic (ČSFR) into two separate States (Slovak Republic, Czech Republic) took place in a constitutional and peaceful manner. See Table 9 and Chart 9 for more information. 
INSIGHTS INTO REGIONAL DEVELOPMENT

ISSN 2669-0195 (online) http://jssidoi.org/jesi/

2021 Volume 3 Number 1 (March)

http://doi.org/10.9770/IRD.2021.3.1(6)

Table 9 Do you think that the creation of an independent Slovak Republic has brought peace and stability within the Central European area?

\begin{tabular}{|c|c|c|c|c|c|c|c|c|}
\hline \multirow{2}{*}{} & \multicolumn{4}{|c|}{ Slovak Republic } & \multicolumn{4}{c|}{ Czech Republic } \\
\cline { 2 - 4 } & \multicolumn{3}{|c|}{ Number of respondents } & \multirow{2}{*}{$\%$} & \multicolumn{3}{c|}{ Number of respondents } & \multirow{2}{*}{$\%$} \\
\cline { 2 - 5 } \cline { 6 - 8 } & Women & Men & Altogether & & Women & Men & Altogether & \\
\hline Yes & 123 & 53 & 176 & $\mathbf{4 2 . 7}$ & 80 & 78 & 158 & $\mathbf{3 6 . 1}$ \\
\hline No & 52 & 22 & 74 & $\mathbf{1 8 . 0}$ & 48 & 71 & 119 & $\mathbf{2 7 . 2}$ \\
\hline Not know & 121 & 41 & 162 & $\mathbf{3 9 . 3}$ & 95 & 66 & 161 & $\mathbf{3 6 . 7}$ \\
\hline Altogether & 296 & 116 & 412 & $\mathbf{1 0 0}$ & 223 & 215 & 438 & $\mathbf{1 0 0}$ \\
\hline
\end{tabular}

Source: Processed based on the results of own research.

Chart 9 Do you think that the creation of an independent Slovak Republic has brought peace and stability within the Central European area?

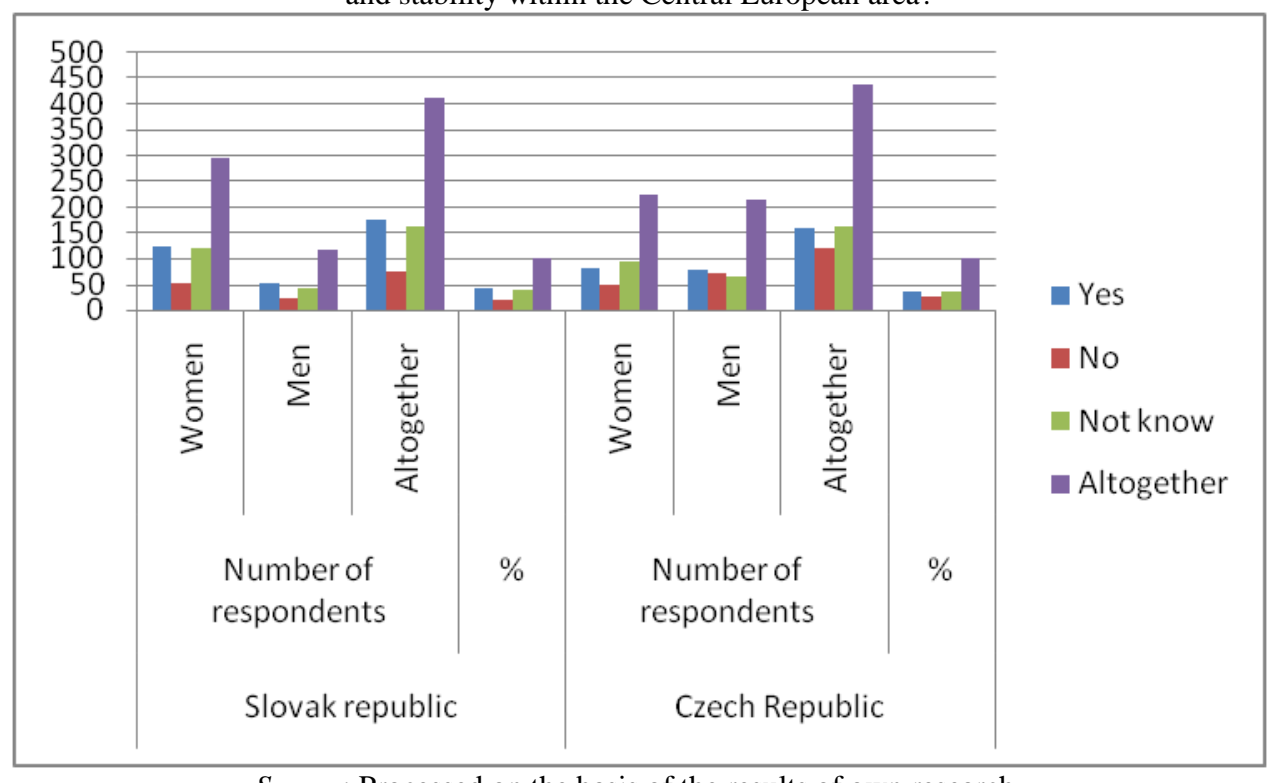

Source: Processed on the basis of the results of own research.

In the tenth question, the only open question in the questionnaire, the selected pupils of elementary and secondary schools of the Zlín self-governing Region (Czech Republic) and the Trenčín self-governing Region (Slovak Republic) had the opportunity to express their opinion on the division of the Czech and Slovak Federative Republic (ČSFR) into two separate States (Slovak Republic, Czech Republic). In both the Slovak Republic and the Czech Republic, most of the respondents expressed their affirmative view on the division of the CzechoSlovak Federation. On the other hand, large proportion of them did not express themselves at all, or could not assess or have not formed any view on the division of Czecho-Slovakia. In both Republics, negligible part of the respondents were in favour of continuing with one common State. For more information see Table 10 and Chart 10. 
INSIGHTS INTO REGIONAL DEVELOPMENT

ISSN 2669-0195 (online) http://jssidoi.org/jesi/

2021 Volume 3 Number 1 (March)

http://doi.org/10.9770/IRD.2021.3.1(6)

Table 10 After more than a quarter of century, how do you see the division of the Czech and Slovak Federative Republic?

\begin{tabular}{|c|c|c|c|c|c|c|c|c|}
\hline \multirow{2}{*}{} & \multicolumn{3}{|c|}{ Slovak Republic } & \multicolumn{5}{c|}{ Czech Republic } \\
\cline { 2 - 9 } & \multicolumn{2}{|c|}{ Number of respondents } & & \multicolumn{3}{c|}{ Number of respondents } & \\
\cline { 2 - 9 } & Women & Men & Altogether & \% & Women & Men & Altogether & \% \\
\hline Didn't answer & 74 & 25 & 99 & $\mathbf{2 4 . 0}$ & 56 & 36 & 92 & $\mathbf{2 1 . 0}$ \\
\hline Didn't know & 56 & 31 & 87 & $\mathbf{2 1 . 1}$ & 53 & 50 & 103 & $\mathbf{2 3 . 5}$ \\
\hline Affirmative & 116 & 40 & 156 & $\mathbf{3 7 . 9}$ & 70 & 65 & 135 & $\mathbf{3 0 . 8}$ \\
\hline Didn't nota (Didn't care) & 28 & 7 & 35 & $\mathbf{8 . 5}$ & 28 & 38 & 66 & $\mathbf{1 5 . 1}$ \\
\hline Stay together & 22 & 13 & 35 & $\mathbf{8 . 5}$ & 16 & 26 & 42 & $\mathbf{9 . 6}$ \\
\hline Altogether & 296 & 116 & 412 & $\mathbf{1 0 0}$ & 223 & 215 & 438 & $\mathbf{1 0 0}$ \\
\hline
\end{tabular}

Source: Processed based on the results of own research.

Chart 10 After more than a quarter of century, how do you see the division of the Czech and Slovak Federative Republic?

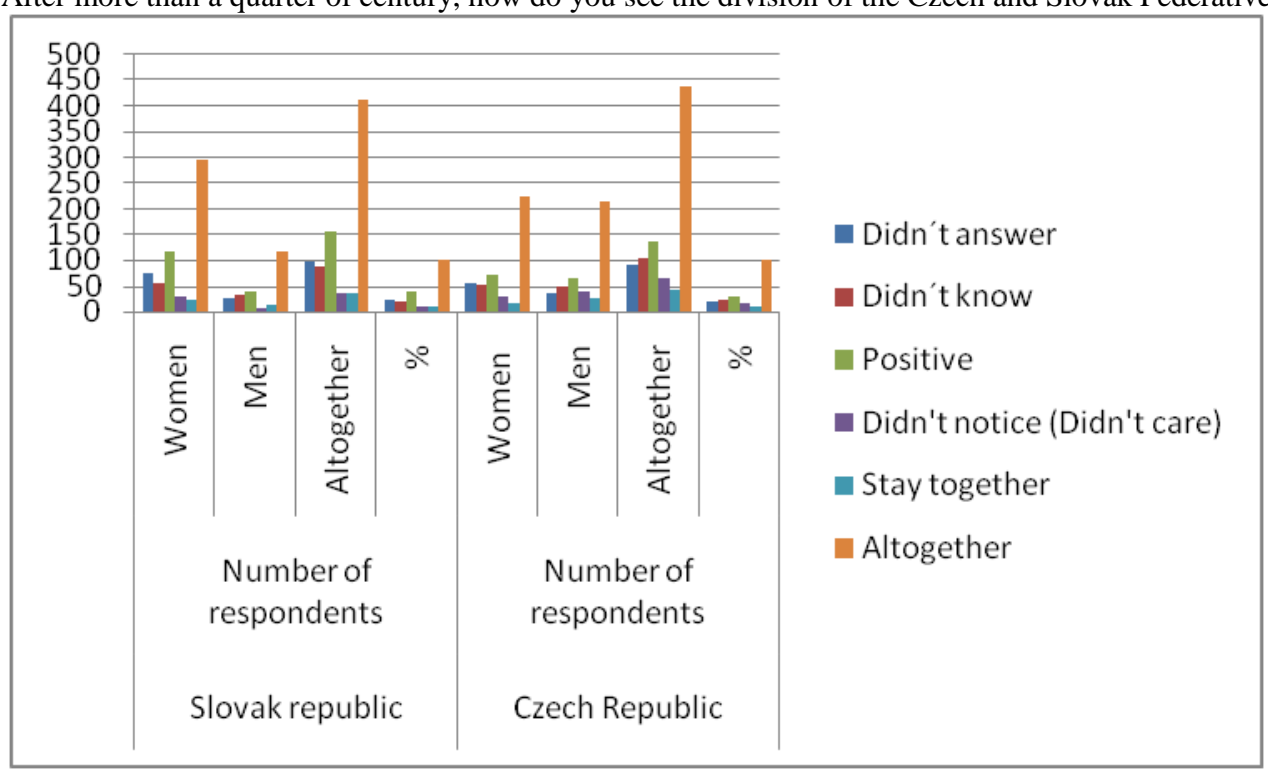

Source: Processed based on the results of own research.

In the eleventh question, we have asked the pupils whether they could imagine the Slovak and Czech Republics united again into one single State in the future? Here, most respondents in both the Slovak Republic and the Czech Republic expressed negative comments. On the other hand, as much as 40,4\% of the respondents in the Czech Republic can imagine the restoration of Czecho-Slovakia, because to date many Czechs have seen the former Czecho-Slovak Republic as the so-called Czech state extended over to the Slovak territory. In the Slovak Republic, only 30,3\% of the respondents can imagine the Slovak Republic and the Czech Republic united. For more information see Table 11 and Chart 11. 
INSIGHTS INTO REGIONAL DEVELOPMENT

ISSN 2669-0195 (online) http://jssidoi.org/jesi/

2021 Volume 3 Number 1 (March)

http://doi.org/10.9770/IRD.2021.3.1(6)

Table 11 Can you imagine the Slovak and the Czech Republics united again into one single State?

\begin{tabular}{|c|c|c|c|c|c|c|c|c|}
\hline \multirow{2}{*}{} & \multicolumn{4}{|c|}{ Slovak Republic } & \multicolumn{4}{c|}{ Czech Republic } \\
\cline { 2 - 4 } & \multicolumn{3}{|c|}{ Number of respondents } & \multirow{2}{*}{$\%$} & \multicolumn{3}{c|}{ Number of respondents } & \multirow{2}{*}{$\%$} \\
\cline { 2 - 6 } \cline { 6 - 8 } & Women & Men & Altogether & & Women & Men & Altogether & \\
\hline Yes & 87 & 38 & 125 & $\mathbf{3 0 . 3}$ & 84 & 93 & 177 & $\mathbf{4 0 . 4}$ \\
\hline No & 181 & 63 & 244 & $\mathbf{5 9 . 2}$ & 125 & 99 & 224 & $\mathbf{5 1 . 1}$ \\
\hline Not know & 28 & 15 & 43 & $\mathbf{1 0 . 5}$ & 14 & 23 & 37 & $\mathbf{8 . 5}$ \\
\hline Altogether & 296 & 116 & 412 & $\mathbf{1 0 0}$ & 223 & 215 & 438 & $\mathbf{1 0 0}$ \\
\hline
\end{tabular}

Chart 11 Can you imagine the Slovak and the Czech Republics united again into one single State?

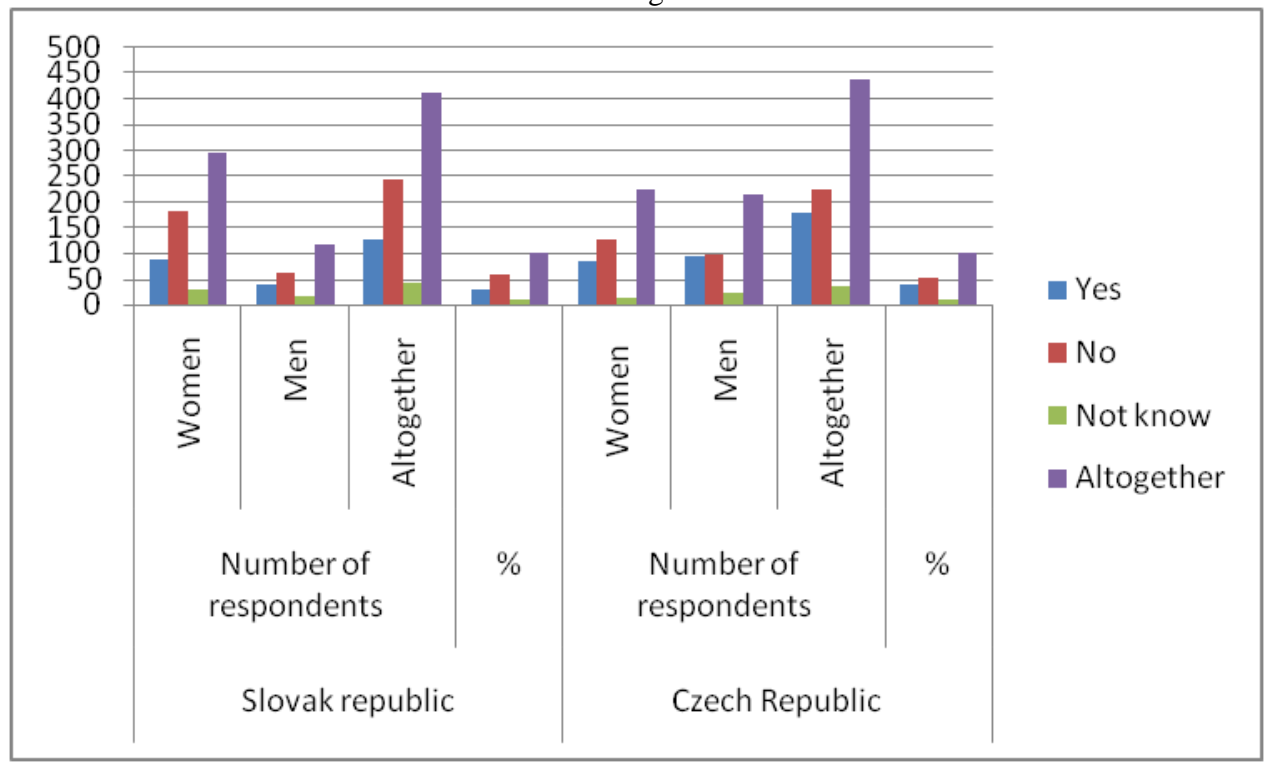

Source: Processed based on the results of own research.

\section{Discussion}

Analysing the first research question, we have found that most pupils in the Slovak Republic consider the share of pro-national Slovak intelligence as decisive in shaping the independent and democratic Slovak Republic. Vast majority of them also agreed with our claim that the Czech nation did not create equal conditions of coexistence with the Slovak nation throughout the whole existence of the Czecho-Slovak Republic; however, this view was not accepted by the majority of respondents in the Czech Republic. Approximately the same percentage of respondents in the Slovak Republic and the Czech Republic agreed that the new democratic establishment after November 1989 created preconditions for a gradual dissolution of the Czech and Slovak Federative Republic.

As part of the second research question, we found that in the Slovak Republic up to 48,3\% of pupils think that the Czech political and lay public could not sufficiently understand the Slovak requirements promoting equality of the Slovak nation within the Czech and Slovak Federative Republic (ČSFR). In contrast, only 23,5\% of respondents 


\section{INSIGHTS INTO REGIONAL DEVELOPMENT}

ISSN 2669-0195 (online) http://jssidoi.org/jesi/

2021 Volume 3 Number 1 (March)

http://doi.org/10.9770/IRD.2021.3.1(6)

shared this view in the Czech Republic. Most respondents in the Slovak Republic and the Czech Republic do not think that Slovakia was an economic obstacle in Czecho-Slovakia. In the Czech Republic, however, up to 30,8\% of respondents thought that Slovakia was indeed an economic obstacle for Czecho-Slovakia. We were also able to find out that up to 30,6\% of the respondents in the Slovak Republic thinks that the division of the Czech and Slovak Federative Republic was mainly promoted by the Czech political public. On the contrary, in the Czech Republic, only $17,4 \%$ of respondents agreed to this claim. Up to $55,9 \%$ of respondents opposed our claim.

As part of the third research question, we found that most students in the Slovak Republic and the Czech Republic agreed with our claim that the division of the Czech and Slovak Federative Republic led to a gradual improvement of mutual Slovak-Czech and Czech-Slovak relations. As to our claim that during the existence of the Czecho-Slovak Republic, Slovaks gradually established themselves as a state-building nation, up to $54,4 \%$ of respondents in the Slovak Republic and only 35,4\% of them in the Czech Republic agreed. 42,7\% of respondents in the Slovak Republic believe that the creation of an independant Slovak Republic brought peace of stability in the Central European Area, while in the Czech Republic only 36,1\% of respondents agreed to this statement. Division of the Czech and Slovak Federative Republic (ČSFR) into two separate States (Slovak Republic, Czech Republic) is positively perceived by most respondents in the Slovak Republic, as well as in the Czech Republic. Finally, we found that most of the respondents in the Slovak Republic and the Czech Republic could not imagine Slovak and Czech Republics united again in one single state in the future.

Division of the Czech and Slovak Federative Republic (ČSFR) into two separate States (Slovak Republic, Czech Republic) has improved mutual relations of Slovak and Czech nations, reaching a high quality level. To date, they, as autonomous and sovereign Member States of the European Union, NATO, V4, work together to promote joint interests.

\section{Conclusions}

On the basis of the carried out comparative analysis of the views and knowledge of the pupils of selected elementary and secondary schools of the Zlín self-governing region (Czech Republic) and the Trenčín selfgoverning region (Slovak Republic) on the division of the Czech and Slovak Federative Republic (ČSFR) into two separate States, several positions and conclusions can be drawn:

Research has shown valuable information about the views of those young people who did not live at the time of the division of Czechoslovakia into two separate States. Outcomes of the research carried out clearly shows that in some areas Slovak and Czech pupils hold different views on the common Slovak-Czech and Czech-Slovak history. On the other hand, most of those in the Slovak Republic and the Czech Republic positively assessed the division of the Czech and Slovak Federative Republic into two separate States (Slovak Republic, Czech Republic) positively. Research also suggests that the current young Slovak generation has largely identified itself with the existence of an independent and democratic Slovak Republic.

It would be beneficial for the whole Slovak and Czech public to have a better understanding of this issue in the future. Similar research with a sample of other age categories within the whole of the Slovak Republic and the Czech Republic could be carried out in the future. Experts would thus obtain further information drawn from the views of the whole Slovak and Czech society.

As for civic education and history classes taught in elementary and secondary schools, we recommend more intensive education on the topic of division of the Czech and Slovak Federative Republic and the subsequent creation of an independent and democratic Slovak Republic as of 1 January 1993. We also recommend that teachers take a partisan-free position to this issue and explain their pupils, in an objective manner, all the events which had led to the gradual collapse of the Czecho-Slovak Federation in the post-November period. In this way, 
INSIGHTS INTO REGIONAL DEVELOPMENT

ISSN 2669-0195 (online) http://jssidoi.org/jesi/

2021 Volume 3 Number 1 (March)

http://doi.org/10.9770/IRD.2021.3.1(6)

natural and "healthy" patriotic spirit could be formed among young people, leading them to appreciate the Slovak nation and all citizens living in the Slovak Republic.

\section{References}

Čársky, J. 2018. (Un)credibility as a tool of political marketing in an election campaign. In: International Relations 2018: Current issues of world economy and politics, Conference proceedings 19th International Scientific Conference. Bratislava: University of Economics in Bratislava Faculty of International Relations. ISBN: 978-80-225-4602-7. p. 119-127.

Hrivík, P. 2012. On the way to modern Slovak statehood: Return to some fateful events in the parliament of the Czech and Slovak Federative Republic. In: Slovaks and their national existence in Europe: the establishment of the 2nd Slovak Republic. Bratislava: PanSlavic Union, 2012. ISBN 978-80-970685-3-0, p.7-75

Hrivík, P. 2017. How and Where to go on, the European Union? In: International Relations 2017: Current issues of world economy and politics, Conference proceedings 18th International Scientific Conference. Bratislava: University of Economics in Bratislava Faculty of International Relations. ISBN 978-80-225-4488-7. p. 386-391.

Hrivík, P., Mindár, M. 2018. Quarter-century of Slovakia's participation within european integration and certain risks resulting from the EU's evolution. In: International Relations 2018: Current issues of world economy and politics, Conference proceedings 19th International Scientific Conference Bratislava: University of Economics in Bratislava Faculty of International Relations. ISBN: 978-80-225-4602-7. p. 236-249.

Hrnko, A. 2016. Establishment of the Slovak Republic on January 1, 1993. In: Siločiary (Scientific journal on economics and politics). Bratislava: Slovak Economic Society - Independent Association of Economists of Slovakia, 2016. Volume XIV. Issue.1. ISSN 1336-4634, p. 53-63.

Hrnko, A. 2017. The desire for one's own state came true (25 years ago, the current Slovak Republic was established). In: The national calendar 2018. Martin: Matica slovenská, 2017. ISBN 978-80-8128-198-3, p. 43-49.

Hrnko, A. 2018. From the establishment of the requirement of the Slovak national self-government to the declaration of the sovereign Slovak Republic. In: Slovak constitutional efforts in the twentieth century. Martin: Matica slovenská, 2018, ISBN 978-80-8128-225-6, p. 465-483.

Janas, K. 2017. Progress in Slovak - Macedonian Relations. In: International Relations 2017: Current issues of world economy and politics, Conference proceedings 18th International Scientific Conference. Bratislava: University of Economics in Bratislava Faculty of International Relations. ISBN 978-80-225-4488-7. p. 428- 435.

Janas, K. 2019. Štefan Závodník and Monuments Dedicated to St. Cyril and Methodius in the District of Považská Bystrica. In: Constantine's Letters. Nitra: Constantine the Philosopher University, 2019, Volume 12. Issue 2. ISSN 1337-8740, p. 107-116.

Kádeková, Z., Savov, R., Košičiarová, I., Valášková, K. 2020.CSR Activities and Their Impact on Brand Value in Food Enterprises in Slovakia Based on Foreign Participation. In: Sustainability. Volume 12 Number 6 (2020), ISSN 2071-1050 (online) p. 4856, https://doi.org/10.3390/su12124856

Laluha, I. 2016. Starting points and ways to the establishment of the Slovak Republic in 1993. From the federation to the establishment of independent republics. In: Perspectives on Slovak Politics after 1989 Part I. Bratislava: Veda, publishing house of the Slovak Academy of Sciences, 2016. ISBN 978-80-224-1514-9, p. 428-547.

Lincényi, M. 2018. A survey of Slovaks' views on the future of the European Union. In: International Relations 2018: Current issues of world economy and politics, Conference proceedings 19th International Scientific Conference Bratislava: University of Economics in Bratislava Faculty of International Relations. ISBN: 978-80-225-4602-7. p. 424-435.

Lincényi, M., Čársky, J. 2020. Policy trusts in public policy in the Slovak Republic. In: Insights into regional development. Volume 2 Number 1 (March). ISSN 2669-0195 (online) p. 456- 468. https://jssidoi.org/ird/article/31 
INSIGHTS INTO REGIONAL DEVELOPMENT

ISSN 2669-0195 (online) http://jssidoi.org/jesi/

2021 Volume 3 Number 1 (March)

http://doi.org/10.9770/IRD.2021.3.1(6)

Mindár, M. 2018. The development of the role of the Czech and Slovak political representation on the state agreement of the Czech and Slovak Federative Republic (CSFR) and its dissolution. In: Internationak Masaryk Conference for PH.D. students and young researchers. MMK 2018: Reviewed proceedings of the International Scientific Conference on. Hradec Králové: Magnanimitas, 2018. ISBN 978-8087952- 27-6. roč. IX, p. 907-915, CD ROM

Rychlík, J. 2015. Czechs and Slovaks in the 20th Century: Cooperation and Conflicts 1914-1992. Second edition. Prague: Vyšehrad publishing house, 688 p. ISBN 978-80-7429-631-4.

Stein, E. 2000. Czecho-Slovakia (Conflict, rupture, disintegration). 1st edition. Prague: Academia, published by the Academy of Sciences of the Czech Republic, 371 p. ISBN 80- 200-0752-0.

Světlík, J., Bulanda, I. 2019. The shift of value types of the Czech population and its influence on the formation of creative advertising strategy. In: Marketing Identity: Offline Is the New Online. Conference Proceedings from the International Scientific Conference. ISBN: 978-80-572-0038-3. p. 323-334.

Žatkuliak, J. 2008. Factors of disintegration of the Czecho-Slovak state at the turn of the 80s and 90s. In: Integration and disintegration processes in Central Europe in the 20th century. Bratislava: Institute of Political Sciences Slovak Academy of Sciences- Center for European Policy, ISBN 978-80-224-1000-7, s. 261-279

\section{Acknowledgements}

This research was carried out in the framework of the project KEGA 003TnUAD-4/2018: Innovation of toxicological air for teachers of civil education from the point of view of prevention of interventions of extreme and poor education for democratic citizenship.
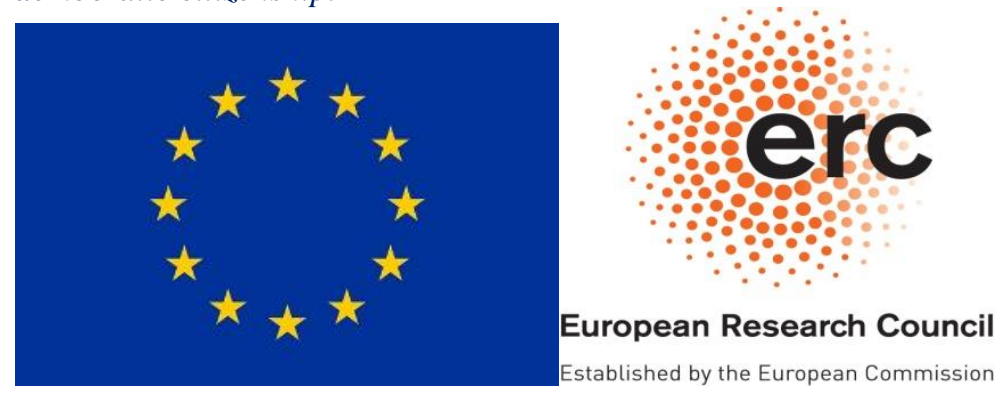

Marcel LINCÉNYI, PhD. in Media studies, obtained at Constantine the Philosopher University in Nitra, currently at Department of Political Science as associate professor, Trenčín University of Alexander Dubček in Trenčín (TnUAD), Slovakia. ORCID ID: https://orcid.org/0000-0002-9076-026X

Marcel MINDÁR, Mgr. is currently assistant at the Department of Political Science, Alexander Dubček University of Trenčín

ORCID ID: https://orcid.org/0000-0003-3822-8660

Copyright (C) 2021 by author(s) and VsI Entrepreneurship and Sustainability Center

This work is licensed under the Creative Commons Attribution International License (CC BY). http://creativecommons.org/licenses/by/4.0/

http://creativeci Open Access 